\title{
Acid-Basic and Complexation Properties of a Sedimentary Humic Acid. A Study on the Barra Bonita Reservoir of Tietê River, São Paulo State, Brazil
}

\author{
Gilberto Abate and Jorge C. Masini \\ Instituto de Química, Universidade de São Paulo, C. P. 26077, 05513-970, São Paulo, SP, Brazil
}

\begin{abstract}
Estudaram-se as propriedades ácido-base e de complexação de ácido húmico (AH) isolado de sedimento de rio por titulação potenciométrica, adotando-se o modelo de distribuição de sítios discretos e funções de Gran modificadas para tratamento dos dados. Foram caracterizadas seis classes de grupos tituláveis, com valores de pK entre 2,4 e 10,2. Grupos carboxílicos contribuiram com 66\% do total de sítios ionizáveis. Estudaram-se as propriedades complexométricas com os íons $\mathrm{Cu}^{2+}$, $\mathrm{Pb}^{2+}, \mathrm{Cd}^{2+}$ e $\mathrm{Zn}^{2+}$ através de titulações potenciométricas com eletrodo íon-seletivo para $\mathrm{Cu}$ ou eletrodos de amálgama $(\mathrm{Pb}, \mathrm{Cd}$ e $\mathrm{Zn})$. O tratamento dos dados pelo método de Scatchard revelou a existência de duas classes de sítios complexantes para cobre e chumbo e uma classe para cádmio e zinco. As constantes de estabilidade médias seguiram a ordem: $\log \mathrm{KAH}-\mathrm{Cu}>\log \mathrm{KAH}-\mathrm{Pb}>\log$ $\mathrm{KAH}-\mathrm{Cd} \cong \log \mathrm{KAH}-\mathrm{Zn}$, e a ordem da capacidade complexante, $\mathrm{C}_{\mathrm{c}}$, foi: $\mathrm{Pb}>\mathrm{Cu}>\mathrm{Cd} \cong \mathrm{Zn}$.
\end{abstract}

Acid-base and complexation properties of humic acid (HA) isolated from a river sediment were studied by potentiometric titration, adopting the discrete site distribution model and the modified Gran functions for data fitting. Six classes of titratable groups were characterized, with $\mathrm{pKa}$ values between 2.4 and 10.2. Carboxylic groups accounted for $66 \%$ of the total of ionizable sites. The complexing properties were studied with regard to $\mathrm{Cu}^{2+}, \mathrm{Pb}^{2+}, \mathrm{Cd}^{2+}$ and $\mathrm{Zn}^{2+}$ ions by potentiometric titration using $\mathrm{Cu}$ ion selective electrode, or amalgam electrodes $(\mathrm{Pb}, \mathrm{Cd}$ and $\mathrm{Zn})$. The data treatment by the Scatchard method revealed two binding sites for copper and lead and one binding site for cadmium and zinc. The average stability constants were in the following order: $\log \mathrm{KHA}-\mathrm{Cu}>\log \mathrm{KHA}-\mathrm{Pb}>\log$ $\mathrm{KHA}-\mathrm{Cd} \cong \log \mathrm{KHA}-\mathrm{Zn}$, while the complexing capacity order, $\mathrm{C}_{\mathrm{c}}$, was: $\mathrm{Pb}>\mathrm{Cu}>\mathrm{Cd} \cong \mathrm{Zn}$.

Keywords: humic acid, acid-base titrimetry, river sediment, complexation capacity

\section{Introduction}

Trace heavy metals introduced into lake and reservoir waters by riverine or atmospheric inputs are involved in a number of chemical, biological and physical processes that determine their concentrations in the aqueous phase, as well as in the suspended particles and sediments. The most important processes for heavy metals removal from the water column are precipitation and settling in association with particulate material, so that sediments are the predominant sink of these toxic species in lakes and reservoirs. Organic carbon (as plankton and biological debris), calcium carbonate, iron and manganese oxy hydroxides, and aluminosilicates are among the major settling particles in lake and reservoir waters ${ }^{1}$. The bioavailability of heavy metals will depend on their affinity with the above mentioned phases of the sediment or suspended matter ${ }^{2-5}$.

e-mail: jcmasini@quim.iq.usp.br
Humic substances are heterogeneous macromolecular aggregates that comprise the main part of natural organic carbon in soils, waters and sediments. These substances are formed in aquatic and terrestrial environments by decomposition of plants, animals and micro-organisms. The large number of ionizable sites on humic substances, mainly carboxylic and phenolic groups, provides an appreciable ability to form stable complexes with heavy metal cations. Humic matter has also the ability to enclose mineral particles, producing aggregates with a significant enhancement in their adsorption or complexation capacity $2,6,7$.

The complexing capacity of humic substances has been mainly reported with regard to copper ions, as the number of moles of metal cations that can be bound per gram of humic matter. The aim of this paper is to study the complexometric properties of humic acid isolated from sediments collected at the Barra Bonita reservoir in the Tietê river with copper, lead, cadmium and zinc ions. This reservoir is located $270 \mathrm{~km}$ downstream from São Paulo City 
(capital of São Paulo State, Brazil), where the river receives a great pollution charge from the metropolitan area, that houses a population near 17 million people. Unlikely other reservoirs closer to São Paulo city, that are very polluted, Barra Bonita reservoir is used as water supply and as a resort area, so that the study of complexation/adsorption properties of the major binding components in this environment would be important to understand the effects of the pollution inputs in upriver areas.

\section{Experimental}

\section{Apparatus and reagents}

Potentiometric measurements were made with two Metrohm $654 \mathrm{pH}$-meters (precision of $0.1 \mathrm{mV}$ or 0.001 units of $\mathrm{pH}$ ). For acid base titration and $\mathrm{pH}$ measurements during complexometric titrations, a Mettler Toledo HA40560-88G-S7/120 - Ag/AgCl combination glass electrode was used. For complexometric titrations both $\mathrm{pH}$-meters were used; one of them was used for monitoring the $\mathrm{pH}$, that was kept at $\mathrm{pH} 6.00 \pm 0.05$ with the aid of the above mentionated combination glass electrode. The other $\mathrm{pH}$ meter was used with an ion selective electrode (ISE-Orion 9429) for $\mathrm{Cu}(\mathrm{II})$, or with a hanging mercury drop electrode (HMDE - Metrohm 6.0335-000) filled with $\mathrm{Pb}, \mathrm{Cd}$ or $\mathrm{Zn}$ amalgams, prepared according previous papers 8,9 , and using a double junction $\mathrm{Ag} / \mathrm{AgCl}$ reference electrode (Mettler 373-90WTEISE-S7/105).

All titrations were performed at $25.0 \pm 0.1^{\circ} \mathrm{C}$. The temperature was controlled by circulating water from an Etica 521D thermostat through the external jacket of the titration cell.

A Gilmont GS 4200 A microburette (capacity of 2.5 $\mathrm{mL}$ and precision of $0.1 \mu \mathrm{L}$ ) was used for titrant addition during the acid base titrations, or for addition of small amounts of a $2 \times 10^{-3} \mathrm{~mol} \mathrm{~L}^{-1} \mathrm{NaOH}$ solution during the complexometric titrations in order to keep the $\mathrm{pH}$ constant at 6.00 \pm 0.05 . A Gilmont GS $1200 \mathrm{~A}$ microburette (capacity of $2 \mathrm{~mL}$ and precision of $2 \mu \mathrm{L}$ ) was used in the complexometric titrations for addition of titrant solutions (5.00 x $10^{-3} \mathrm{~mol} \mathrm{~L}^{-1} \mathrm{Cu}^{2+}, \mathrm{Pb}^{2+}, \mathrm{Cd}^{2+}$ or $\mathrm{Zn}^{2+}$ ).

Spectrophotometric measurements were carried out using a Micronal B-382 spectrophotometer. Elemental analyses $(\mathrm{C}, \mathrm{H}, \mathrm{N})$ were performed with a Perkin-Elmer - Elemental Analyser 2400 CHN. The elements Al, Fe, $\mathrm{Mn}, \mathrm{Cu}, \mathrm{Zn}$ were determined in the Barra Bonita sediment after its digestion using a CG-AA-7000-BC flame atomic absorption spectrometer with deuterium background corrector.

All reagents were of analytical grade from Merck,
Aldrich or Sigma. The preparation of the standard solutions of metallic cations and sodium hidroxide solutions has already been described in the literature ${ }^{9,16-18}$.

\section{Sample preparation}

Humic acid isolation and purification was based on the protocol proposed by the International Humic Substances Society (IHSS) that has been used in several studies $7,10,11$. Sediment samples were collected with a Birge-Eckman dredge in several points of the reservoir and stored in sealed polyethylene bottles at $4^{\circ} \mathrm{C}$, until the HA isolation. Samples were mixed and dried in an open polyethylene container at room temperature for 5 days. About $1.0 \mathrm{~kg}$ of the sediment was used to extract the humic acid in a closed polyethylene container. The first step was the addition of $10 \mathrm{~L}$ of 0.1 mol L-1 $\mathrm{HCl}$ and the adjustment of the $\mathrm{pH}$ between 1 and 2 with $1 \mathrm{~mol} \mathrm{~L}^{-1} \mathrm{HCl}$. The suspension was shaken in a horizontal shaker for one hour and then allowed to settle overnight. The supernatant was discarded, and the $\mathrm{pH}$ of the solid phase was adjusted to 7.0 with $1 \mathrm{~mol} \mathrm{~L}^{-1} \mathrm{NaOH}$, followed by addition of $10 \mathrm{~L}$ of $0.1 \mathrm{~mol} \mathrm{~L}^{-1} \mathrm{NaOH}$ under nitrogen atmosphere, to minimize oxidation of humic material. The container was stoppered under $\mathrm{N}_{2}$ atmosphere, shaken in a horizontal shaker for $4 \mathrm{~h}$, and allowed to rest overnight. The supernatant was centrifuged at $9000 \mathrm{~g}$ for $20 \mathrm{~min}$ and the solid phase was discarded. The humic material in the liquid fraction was precipitated by adding 6 mol L-1 $\mathrm{HCl}$ solution until $\mathrm{pH} 1.0$, and allowed to stand for $15 \mathrm{~h}$. The liquid phase was discarded and the humic acid was dissolved in a suitable volume of $0.1 \mathrm{~mol} \mathrm{~L}^{-1} \mathrm{KOH}$ solution under nitrogen atmosphere. The ionic medium was adjusted to $0.3 \mathrm{~mol} \mathrm{~L}^{-1}$ by addition of $\mathrm{KCl}$, leading to colloid coagulation, and precipitation of a mineral phase that was separated by centrifugation. The $\mathrm{pH}$ of the solution was adjusted to 1.0 , according to previously described, and the humic acid was separated by centrifugation. This material was maintained in $0.1 \mathrm{~mol} \mathrm{~L}^{-1} \mathrm{HCl}$ and $0.3 \mathrm{~mol} \mathrm{~L}^{-1}$ HF overnight to dissolve silica and silicates. Finally, the humic acid fraction was dialysed in a Spectra/Por 7 membrane (molar mass cut-off $=1,000 \mathrm{D}$ ), until no significant change was observed in the conductance of the water external to the dialysis bag.

The suspension was diluted in a volumetric flask and stored at $4^{\circ} \mathrm{C}$. The concentration of the stock was determined as $4.28 \mathrm{~g} \mathrm{~L}^{-1}$ by the dry weight of a measured volume of the homogenized suspension.

\section{Molar mass profile}

The profile of molar mass distribution was studied by gel permeation chromatography ${ }^{12-14}$, using Sephadex G-100 as 
stationary phase and a solution composed of $10^{-3} \mathrm{~mol} \mathrm{~L}^{-1}$ borate buffer $(\mathrm{pH}=9.20)$ in $0.1 \mathrm{~mol} \mathrm{~L}^{-1} \mathrm{NaCl}$ as eluent. A $90 \mathrm{~cm}$ long column with $1.5 \mathrm{~cm}$ of internal diameter was calibrated with globular proteins (Sigma Chemical Co.): 5.0 $\mathrm{mg} \mathrm{mL}^{-1}$ bovine albumin $(66,000 \mathrm{D}), 2.0 \mathrm{mg} \mathrm{mL}^{-1}$ carbonic anhydrase $(29,000 \mathrm{D}), 2.0 \mathrm{mg} \mathrm{mL}^{-1}$ cytochrome C $(12,400$ D) and $3.0 \mathrm{mg} \mathrm{mL}^{-1}$ aprotinin $(6,500 \mathrm{D})$. The void volume of the column was determined with blue dextran marker $(2,000,000 \mathrm{D})$. The flow rate of the mobile phase was kept at $0.718 \pm 0.006 \mathrm{~mL} \mathrm{~min}^{-1}$, and the absorbance was monitored at $280 \mathrm{~nm}$. Humic acid suspensions $\left(1 \mathrm{mg} \mathrm{mL}^{-1}\right)$ in $10^{-3} \mathrm{~mol} \mathrm{~L}^{-1}$ borate buffer and $0.1 \mathrm{~mol} \mathrm{~L}^{-1} \mathrm{NaCl}$ were eluted under the same conditions used for the globular proteins.

\section{Acid-base titrations}

The calibration of the glass electrode was performed just before the humic acid titrations, in terms of $\mathrm{H}^{+}$concentrations instead activities ${ }^{15,16}$.

Titrations were performed with $50.00 \mathrm{~mL}$ of $1.105 \mathrm{~g}$ $\mathrm{L}^{-1}$ humic acid suspensions in ionic medium of $0.1 \mathrm{~mol} \mathrm{\textrm {L } ^ { - }}$ ${ }^{1} \mathrm{NaCl}$ using a standard $0.1 \mathrm{~mol} \mathrm{~L}^{-1} \mathrm{NaOH}$ titrant solution containing the same concentration of $\mathrm{NaCl}$. Also, 50.00 $\mathrm{mL}$ aliquots of $30 \mathrm{mg} \mathrm{L}^{-1} \mathrm{HA}$ suspensions were titrated in 0.02 ionic strength $\left(\mathrm{NaNO}_{3}\right)$ using a standard $0.005 \mathrm{~mol}$ $\mathrm{L}^{-1} \mathrm{NaOH}$ with the same ionic strength. The experimental procedure of the titrations, as well as the data treatment have been described in previous papers ${ }^{16-18}$.

\section{Complexometric titrations}

All titration and calibrations were performed at $25.0 \pm 0.1^{\circ} \mathrm{C}$, in ionic medium of $0.02 \mathrm{~mol} \mathrm{~L}^{-1} \mathrm{NaNO}_{3}$ and pH 6.00 \pm 0.05 . For studies with $\mathrm{Pb}^{2+}, \mathrm{Cd}^{2+}$ and $\mathrm{Zn}^{2+}$, potentiometric amalgam electrodes were prepared according to a previous paper ${ }^{9}$ with the aid of a Metrohm Hanging Mercury Drop Electrode. For these experiments, all solutions were previously degassed with ultrapure $\mathrm{N}_{2}\left(\mathrm{O}_{2}<1\right.$ ppm) for 10 minutes. $\mathrm{A}_{2}$ flow was kept inside the cell during all the titration procedure ${ }^{8}$. For studies with $\mathrm{Cu}^{2+}$ ions, an Orion 9429 copper ion selective electrode (ISE) was used.

The humic acid solutions were prepared in a range of concentrations between 20 and $30 \mathrm{mg} \mathrm{L}^{-1}$. Titrations were performed with $20.00 \mathrm{~mL}$ of humic acid suspension, adding initial increments of $20 \mu \mathrm{L}$ of titrant $\left(5.00 \times 10^{-3} \mathrm{~mol}\right.$ $\mathrm{L}^{-1}$ in $\mathrm{Cu}^{2+}, \mathrm{Pb}^{2+}, \mathrm{Cd}^{2+}$, or $\mathrm{Zn}^{2+}$ ) from a Gilmont GS $1200 \mathrm{~A}$ burette. The $\mathrm{pH}$ was kept constant at $6.00 \pm 0.05$ by adding adequate amounts of $2 \times 10^{-3} \mathrm{~mol} \mathrm{~L}^{-1} \mathrm{NaOH}$ from another burette. The titrant and $\mathrm{NaOH}$ solutions were prepared in $0.02 \mathrm{~mol} \mathrm{~L}^{-1} \mathrm{NaNO}_{3}$. As the titration proceeded, the increments of titrant were increased up to 100 $\mu \mathrm{L}$, so that 30 points of volume and potential were taken. Calibrations were performed similarly with $20.00 \mathrm{~mL}$ of $0.02 \mathrm{~mol} \mathrm{~L}^{-1} \mathrm{NaNO}_{3}$ solution. The amalgam drops were renewed at each titration point after the titrant addition and $\mathrm{pH}$ correction. The potential values were taken after 5 min of equilibration, when the potential drift was smaller than $0.555 \mathrm{mV} \mathrm{min}^{-1}$.

Determination of metals in Barra Bonita sediment and humic acid samples

The content of $\mathrm{Fe}, \mathrm{Mn}, \mathrm{Cu}, \mathrm{Al}, \mathrm{Zn}, \mathrm{Cd}$ and $\mathrm{Pb}$ bounded to the sediment was determined after a digestion, performed as follows: $1.0 \mathrm{~g}( \pm 0.1 \mathrm{mg})$ of dry sediment was boiled with $4 \mathrm{~mL}$ of concentrated $\mathrm{HNO}_{3}$, followed by a digestion with $2 \mathrm{~mL}$ of $30 \%(\mathrm{w} / \mathrm{w}) \mathrm{H}_{2} \mathrm{O}_{2}$ and $1 \mathrm{~mL}$ of concentrated $\mathrm{HNO}_{3}$ until dryness to decompose the organic matter ${ }^{19}$. The solutions were filtered in a $0.45 \mu \mathrm{m}$ Millex ${ }^{\circledR}$ membranes, diluted with $1 \% \mathrm{HNO}_{3}$ in $50.00 \mathrm{~mL}$ volumetric flasks, and then analysed by flame atomic absorption spectrometry with deuterium background corrector. All analyses were performed using air- $\mathrm{C}_{2} \mathrm{H}_{2}$ flame, except $\mathrm{Al}$ that requires $\mathrm{N}_{2} \mathrm{O}-\mathrm{C}_{2} \mathrm{H}_{2}$ flame, and addition of $\mathrm{KCl}$ to avoid ionization effects ${ }^{19}$. The analysis of the humic acid was performed similarly to described for sediment, but only $0.1 \mathrm{~g}$ was used, owing to the small amount of available sample.

\section{Results and Discussion}

\section{Elemental composition and ash contents}

Table 1 shows the results of elemental composition and ash content. The low ash content indicates a good removal of mineral matter in the extraction and purification procedure. The $\mathrm{H} / \mathrm{C}, \mathrm{N} / \mathrm{C}$ and $\mathrm{O} / \mathrm{C}$ elemental ratios (1.05, 0.0767 , and 0.488 , respectively) are essentially in the same range determined by Belzile et al. ${ }^{7}$ for four humic acids isolated from sediments of Canadian lakes and by Ishiwatari for Japanese lakes. ${ }^{20} \mathrm{~A}$ possible explanation for the high N/C elemental ratio for the sedimentary humic acids, in comparison to soil and water humic acids, is their precursor materials, constituted mainly by phytoplankton, where N/C elemental ratios are among 0.11 and 0.16. ${ }^{21}$ The empirical formulae for the Barra Bonita humic acid is C:H:O:N = 13:14:6:1, while Belzile et $\mathrm{al}^{7}$ reported an average formulae from the four humic acids, extracted with $0.5 \mathrm{~mol} \mathrm{~L}^{-1} \mathrm{NaOH}$ or $0.1 \mathrm{~mol} \mathrm{~L}^{-1}$ $\mathrm{Na}_{4} \mathrm{P}_{2} \mathrm{O}_{7}$, as $\mathrm{C}: \mathrm{H}: \mathrm{O}: \mathrm{N}=12: 16: 6: 1$. The $\mathrm{C} / \mathrm{H}$ ratios of 0.93 (Barra Bonita) and 0.75 (Canadian sediments) suggest a more important contribution of aromatic moieties in the Barra Bonita humic acid. 
Table 1. Elemental composition, ash content and molar elemental ratios for the Barra Bonita sediment humic acid.

\begin{tabular}{cccccccc}
\hline $\mathrm{C}(\%)$ & $\mathrm{H}(\%)$ & $\mathrm{N}(\%)$ & $\mathrm{O}(\%)$ & $\mathrm{H} / \mathrm{C}^{*}$ & $\mathrm{~N} / \mathrm{C}^{*}$ & $\mathrm{O} / \mathrm{C}^{*}$ & $\operatorname{ash}(\%)$ \\
\hline 54.1 & 4.7 & 4.8 & 35.1 & 1.05 & 0.0767 & 0.488 & $1.3 \pm 0.1$ \\
\hline
\end{tabular}

*calculated on an ash free basis

\section{Molar mass distribution profile}

Figure 1 shows the elution profile of the humic acid in comparison to globular proteins from the GPC column. It was observed a fraction eluted at the exclusion volume of the column $(2,000,000 \mathrm{D})$, as well as significant contribution of molecules with molar masses over all the calibration range $(6,500$ to $66,000 \mathrm{D})$, and a maximum contribution at $3,701 \pm 117 \mathrm{D}$. These results, however, should be view with care, because severe pitfalls in the molar mass distribution of humic substances have been reported in the literature ${ }^{22}$ resulting from the lack of appropriate standards, once humic substances may not present a globular spatial conformation.

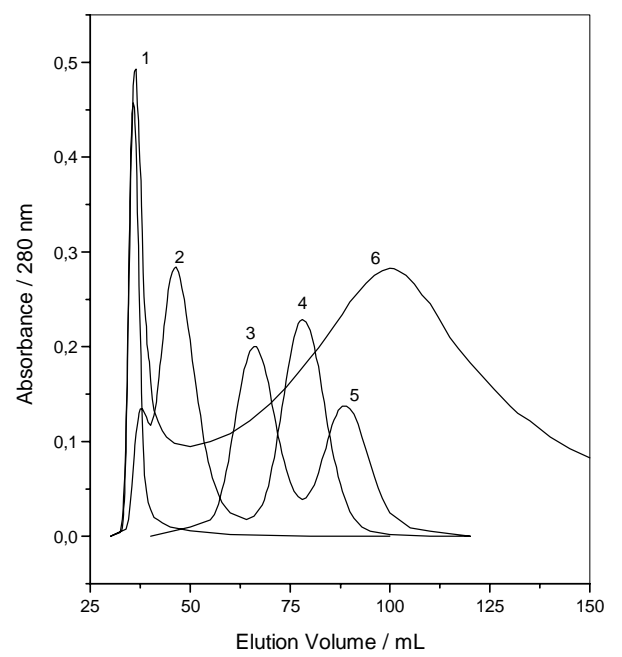

Figure 1. GPC elution curves, $1=$ Blue Dextran (exclusion volume $\mathrm{V}_{0}$ ), 2 = Albumin, 3 = Carbonic Anhydrase, $4=$ Cytochrome $\mathrm{C}$, $5=$ Aprotinin, $6=$ Barra Bonita humic Acid. Stationary phase $=$ Sephadex $\mathrm{G}-100$, eluent $=10^{-3} \mathrm{~mol} \mathrm{~L}^{-1}$ borate buffer $/ 0.1 \mathrm{~mol} \mathrm{~L}^{-1} \mathrm{NaCl}, \mathrm{pH}=9.2$, flow rate $=0.718 \mathrm{~mL} \mathrm{~min}^{-1}$.

\section{Acid-base characterization}

Table 2 shows the stoichiometry and pK of ionizable sites. Six classes of titratable species were characterized by the modified Gran functions in medium of $0.1 \mathrm{~mol} \mathrm{~L}^{-}$ ${ }^{1} \mathrm{NaCl}$, according to Figure 2, that shows the segmented and linearized titration curve. Species $\mathrm{HA}_{1}, \mathrm{HA}_{2}$ and $\mathrm{HA}_{3}$ may be assigned to carboxylic groups, which was evidenced in a previous work, where the sum of groups $\mathrm{HA}_{1}$ to $\mathrm{HA}_{3}$ in Aldrich and vermicompost humic acids was in good agreement with the carboxylic acidity determined by the calcium acetate exchange method ${ }^{16}$.

Table 2. Results of linear regression fittings for acid base potentiometric titration curves of Barra Bonita humic acid suspension in ionic strength $0.1(\mathrm{NaCl})$ and $0.02\left(\mathrm{NaNO}_{3}\right)$.

\begin{tabular}{lcccc}
\hline Ionizable & \multicolumn{2}{c}{$0.1 \mathrm{~mol} \mathrm{~L}^{-1} \mathrm{NaCl}^{\mathrm{a}}$} & $0.02 \mathrm{~mol} \mathrm{~L}^{-1} \mathrm{NaNO}_{3}{ }^{\mathrm{b}}$ \\
Species & $\mathrm{N}\left(\mathrm{mmol} \mathrm{g}^{-1}\right)$ & $\mathrm{pKa}$ & $\mathrm{N}\left(\mathrm{mmol} \mathrm{g}^{-1}\right)$ & $\mathrm{pKa}$ \\
\hline HA1 & $0.45 \pm 0.01$ & $2.4 \pm 0.2$ & $0.50 \pm 0.05$ & - \\
HA2 & $1.75 \pm 0.02$ & $4.20 \pm 0.02$ & $1.45 \pm 0.06$ & $4.88 \pm 0.02$ \\
HA3 & $0.85 \pm 0.03$ & $5.61 \pm 0.04$ & $0.59 \pm 0.01$ & $6.3 \pm 0.1$ \\
$\sum_{n=1}^{3} H A n$ & $3.05 \pm 0.06$ & - & $2.5 \pm 0.1$ & - \\
HA4 & $0.44 \pm 0.01$ & $7.24 \pm 0.07$ & $0.38 \pm 0.01$ & $7.7 \pm 0.3$ \\
HA5 & $0.45 \pm 0.01$ & $8.75 \pm 0.02$ & $0.7 \pm 0.1$ & $9.0 \pm 0.2$ \\
HA6 & $0.66 \pm 0.06$ & $10.2 \pm 0.1$ & - & - \\
$\sum_{n=4}^{6} H A n$ & $1.55 \pm 0.08$ & - & & \\
$\sum_{n=1}^{6} H A n$ & $4.6 \pm 0.1$ & - & $3.1 \pm 0.1$ & - \\
\hline
\end{tabular}

$\mathrm{n}=3$

Humic acid concentration: $\mathrm{a}=1.105 \mathrm{~g} \mathrm{~L}^{-1} ; \mathrm{b}=30 \mathrm{mg} \mathrm{L}^{-1}$

$\mathrm{N}=$ concentration of ionizable sites HAn

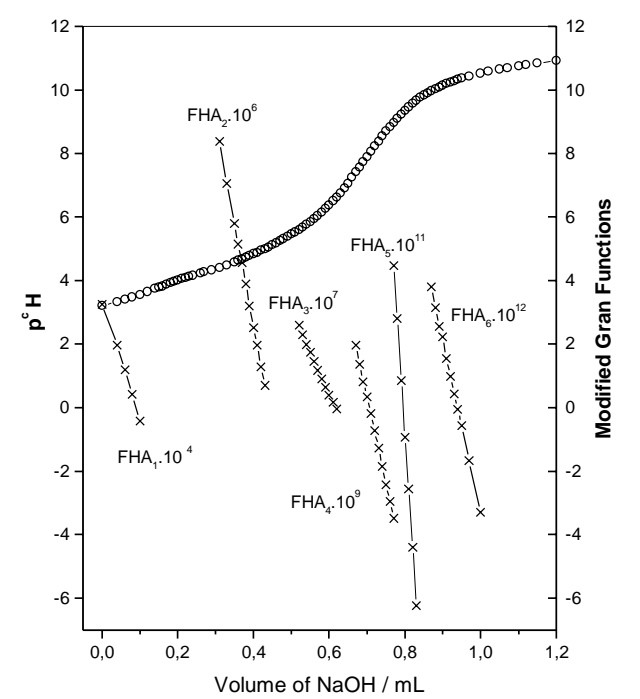

Figure 2. Titration curve of $20.00 \mathrm{~mL}$ of $1.105 \mathrm{~g} \mathrm{~L}^{-1}$ Barra Bonita humic acid suspension in ionic medium of $0.1 \mathrm{~mol} \mathrm{~L}^{-1} \mathrm{NaCl}$, linearized by modified Gran functions $\left(\mathrm{FHA}_{\mathrm{n}}\right)$. Titrant $=0.1090 \mathrm{~mol} \mathrm{~L}^{-1} \mathrm{NaOH}$, temperature $=25.0 \pm 0.1^{\circ} \mathrm{C}$.

Species $\mathrm{HA}_{4}$ may be assigned to carboxylic groups titratable with unusually high $\mathrm{pKa}$, subject to electrostatic interaction due to accumulation of negative charges on the macromolecule, that becomes more intense as the $\mathrm{pH}$ increases during the titration. Species $\mathrm{HA}_{4}$, however, may be also assigned to $\mathrm{N}$ containing ionizable sites. Species $\mathrm{HA}_{5}$ and $\mathrm{HA}_{6}$ may be assigned to phenolic sites. The sum of species $\mathrm{HA}_{4}, \mathrm{HA}_{5}$ and $\mathrm{HA}_{6}$, corresponds to $33.7 \%$ of ionizable species. 
About $57.4 \%$ of the carboxylic groups (sum of $\mathrm{HA}_{1}$ to $\left.\mathrm{HA}_{3}\right)$ presented a pKa of $4.20\left(\mathrm{HA}_{2}\right)$, while $15 \%$ presented pKa $2.4\left(\mathrm{HA}_{1}\right)$. This low pKa value may be explained by the location of carboxylic groups in aliphatic $\alpha$-ether or $\alpha$ ester cyclic structures with two or three additional electronegative functional groups at adjacent position on the ring $^{23}$. Keto acid and aromatic carboxyl structure can also account for ionizable groups with $\mathrm{pKa}<3$ in $\mathrm{HA}_{1}$ Species $\mathrm{HA}_{3}{ }^{24}$, corresponding to $27.9 \%$ of carboxylic groups presents a pKa of 5.61, which can reflect local interactions on the macromolecule, as well as the negative charge accumulation effect.

The content of carboxylic and phenolic groups in sedimentary humic acids is usually lower than observed for soil and water humic acids, while the carbonyl contents are higher. The total of $3.06 \mathrm{mmol} \mathrm{g}^{-1}$ groups admitted as carboxylic is in agreement with the literature, that report 2.0 to $4.0 \mathrm{mmol}$ of these groups per gram of sedimentary humic acid $^{3}$. The total of $1.55 \mathrm{mmol} \mathrm{g}^{-1}$ groups determined with $\mathrm{pKa}>7$ (aminic and phenolic) is also within the range between 0.5 and $2.5 \mathrm{mmol} \mathrm{g}^{-1}$ reported in literature for phenolic groups in sedimentary humic acids ${ }^{3}$. Based on the total acidity of $4.6 \pm 0.1 \mathrm{mmol} \mathrm{g}^{-1}$ of the Barra Bonita humic acid, one can speculate the average molar mass for each ionizable site as $217 \mathrm{~g} \mathrm{~mol}^{-1}$. The low content of carboxylic sites in comparison to fulvic acids and humic acids from soils and water ${ }^{3}$ is coherent with the significant contribution of high molar mass fractions in the studied sedimentary humic acid. According with the findings of Falzoni et al 25 who fractionated humic and fulvic acids, the content of carboxylic sites was smaller in higher molar mass fractions.

In order to study the acid-base properties of the humic acid under similar conditions to the complexometric study, alkalimetric titrations were performed in medium of $0.02 \mathrm{~mol}$ $\mathrm{L}^{-1} \mathrm{NaNO}_{3}$, using a HA concentration of $30 \mathrm{mg} \mathrm{L}^{-1}$. The results of these experiments are also shown in Table 2. Only five classes of titratable species were characterized under these conditions, in addition to the fact that the stoichiometry of the species was systematically smaller than observed for concentrated solution in $0.1 \mathrm{~mol} \mathrm{~L}^{-1} \mathrm{NaCl}$ medium. Species $\mathrm{HA}_{1}$ behave as a strong acid and no pKa value was possible to be characterized. The explanation for this behaviour is not clear at this time, but the titration performed in these poorly buffered conditions provides experimental data that are much more subject to error in the $\left[\mathrm{H}^{+}\right]$measurement in comparison to the $1 \mathrm{~g} \mathrm{~L}^{-1}$ humic acid suspension.

\section{Complexometric titrations}

Table 3 presents the values of conditional stability constant $(\log \mathrm{K})$ and complexing capacity $\left(\mathrm{C}_{\mathrm{c}}\right)$ obtained according to Scatchard plots ${ }^{3,6,9,26}$, from the $[\mathrm{ML}] /\left[\mathrm{M}^{2+}\right]$ versus [ML] shown in Figure 3, where $\left[\mathrm{M}^{2+}\right.$ ] represents the concentration of the free cations $\mathrm{Cu}^{2+}, \mathrm{Pb}^{2+}, \mathrm{Cd}^{2+}$ or $\mathrm{Zn}^{2+}$, while [ML] is the concentration of the complexed metal. Since the Scatchard plot is a model that translate the continuous actual distribution of complexing sites to discrete sites, the $\log \mathrm{K}$ described in Table 3 should be thought as average equilibrium values for the cases where only one class of complexing site is characterized $(\mathrm{Cd}$ and $\mathrm{Zn})$. For the cases where two classes of binding sites are characterized $(\mathrm{Cu}$ and $\mathrm{Pb}$ ), the $\log { }^{\mathrm{j}} \mathrm{K}$ and $\mathrm{j}_{\mathrm{c}}$ values are not only average values, but mixed values among the stronger and weaker classes of complexing sites, since it is very difficult to completely isolate the individual contribution of these sites, as is evidenced by the continuous curvature observed in the Scatchard plots for $\mathrm{Cu}$ and $\mathrm{Pb}$.

Copper forms the most stable complexes in comparison to other three cations. The binding site of class 1 (Table 3 ) binds copper with $\log$ K $7.8 \pm 0.1$ corresponding to complexes more stable than those formed with the class 2 of binding sites. The complexing capacity of the binding sites of class 1 is approximately a half of the class 2 , while the total copper complexing capacity was 1,300 $\mu \mathrm{ol} \mathrm{g}^{-1}$. From the acid-base potentiometric results obtained in ionic medium of $0.1 \mathrm{~mol} \mathrm{~L}^{-1} \mathrm{NaCl}$ and humic acid concentration of $1.105 \mathrm{~g} \mathrm{~L}^{-1}$, it is possible to estimate that at $\mathrm{pH} 6.0$, there are $2,803 \mu \mathrm{mol} \mathrm{g}^{-1}$ of free carboxylate sites. From these data, one can speculate that if each copper ion is complexed by binding sites that involve two ionizable sites, forming bidentade chelates, the $1,300 \mu \mathrm{mol} \mathrm{g}-1$ of copper would occupy $93 \%$ of the dis-

Table 3. Results ${ }^{\mathrm{a}}$ of conditional stability constants $\left({ }^{\mathrm{j}} \mathrm{K}\right)$ and complexing capacity $\left({ }^{\mathrm{j}} \mathrm{C}_{\mathrm{c}}\right)$ for the Barra Bonita humic acid at $25.0 \pm 0.1^{\circ} \mathrm{C}$, $\mathrm{pH}=6.00 \pm 0.05$ and ionic medium of $0.02 \mathrm{~mol} \mathrm{~L}^{-1} \mathrm{NaNO}_{3}$.

\begin{tabular}{|c|c|c|c|c|c|c|}
\hline ion & $\log { }^{1} \mathrm{~K}^{\mathrm{b}}$ & ${ }^{1} \mathrm{C}_{\mathrm{c}}\left(\mu \mathrm{mol} \mathrm{g}{ }^{-1}\right)$ & $\log ^{2} \mathrm{~K}$ & ${ }^{2} \mathrm{C}_{\mathrm{c}}\left(\mu \mathrm{mol} \mathrm{g}{ }^{-1}\right)$ & $\sum_{j=1}^{2} \mathrm{j}_{\mathrm{c}}\left(\mu \mathrm{mol} \mathrm{g}{ }^{-1}\right)$ & $\Delta \mathrm{H}^{+}\left(\mu \mathrm{mol} \mathrm{g}{ }^{-1}\right)^{\mathrm{c}}$ \\
\hline $\mathrm{Cu}^{2+}$ & $7.8 \pm 0.1$ & $420 \pm 20$ & $6.0 \pm 0.1$ & $900 \pm 300$ & $1300 \pm 300$ & $54 \pm 3$ \\
\hline $\mathrm{Pb}^{2+}$ & $5.6 \pm 0.1$ & $1800 \pm 100$ & $5.0 \pm 0.2$ & $600 \pm 100$ & $2400 \pm 200$ & $33 \pm 2$ \\
\hline $\mathrm{Cd}^{2+}$ & $4.8 \pm 0.1$ & $800 \pm 100$ & - & - & $800 \pm 100$ & $12 \pm 2$ \\
\hline $\mathrm{Zn}^{2+}$ & $4.89 \pm 0.06$ & $940 \pm 10$ & - & - & $940 \pm 10$ & $22 \pm 3$ \\
\hline
\end{tabular}

a Results correspond to an average of five experiments; ${ }^{b}$ The expoents 1 and 2 in $\log \mathrm{K}$ and $\mathrm{C}_{\mathrm{c}}$ referes to the binding sites of class $\mathrm{j}=1$ and $\mathrm{j}=2$ respectively; ${ }^{\mathrm{c}} \Delta \mathrm{H}^{+}$is the amount of $\mathrm{H}^{+}$liberated from HA titration in comparison with the blank titration. 

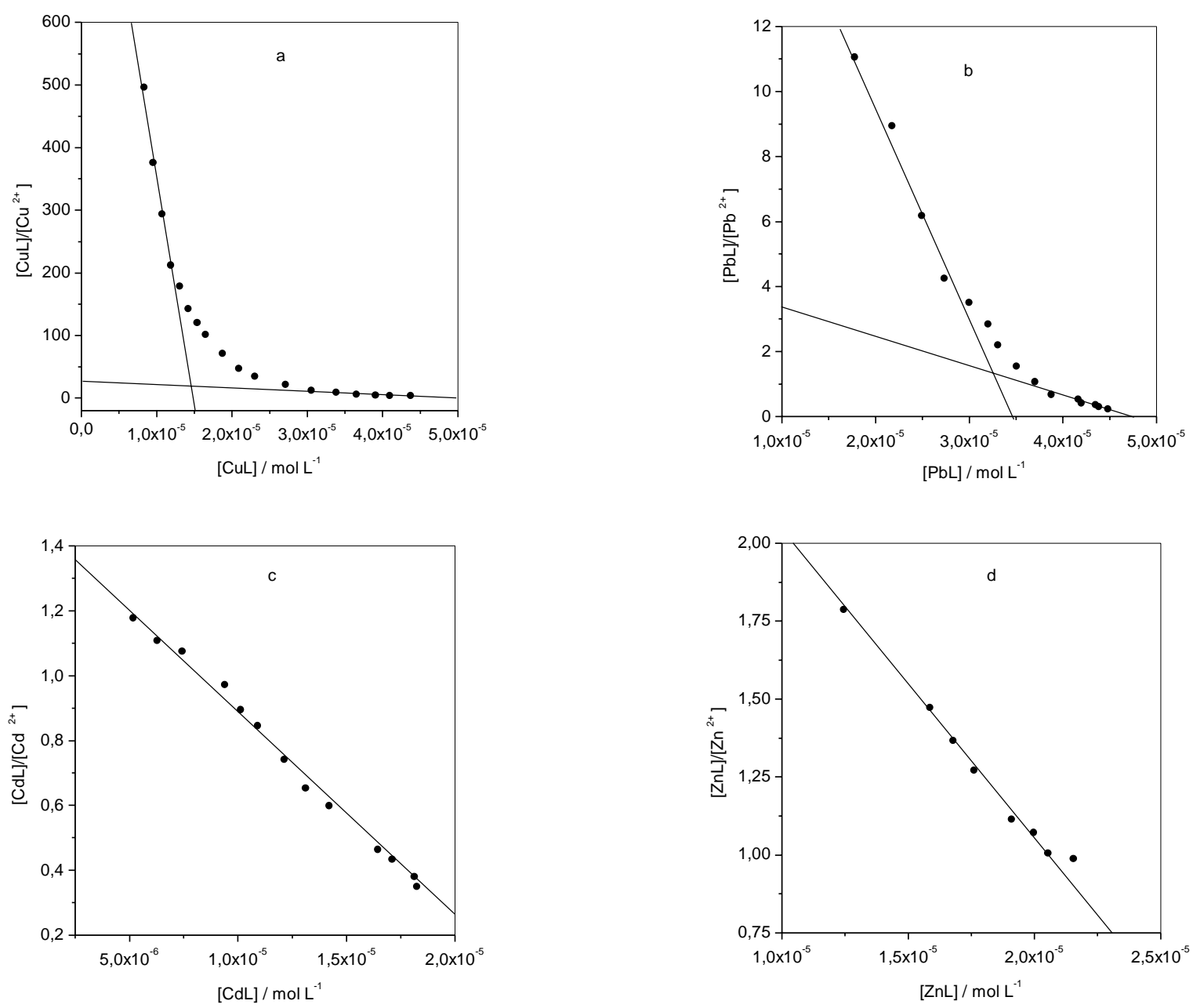

Figure 3. Scatchard plots obtained for Barra Bonita humic acid suspensions (BBHA). $\mathrm{a}=\mathrm{Cu}, \mathrm{b}=\mathrm{Pb}, \mathrm{c}=\mathrm{Cd}, \mathrm{d}=\mathrm{Zn}$. Titration conditions: $\mathrm{Cu}$ and $\mathrm{Cd}$, volume $=20.00 \mathrm{~mL}$ of $33.15 \mathrm{mg} \mathrm{L}^{-1}$ suspension; $\mathrm{Pb}$, volume $=20.00 \mathrm{~mL}$ of $22.10 \mathrm{mg} \mathrm{L}^{-1}$ suspension; $\mathrm{Zn}$, volume $=40.00 \mathrm{~mL}^{\circ} 33.15 \mathrm{mg} \mathrm{L}-1$ suspension. $\mathrm{pH}=6.00 \pm 0.05$, in ionic medium $0.02 \mathrm{~mol} \mathrm{~L}^{-1} \mathrm{NaNO}_{3}$. Titrant concentration $=5.00 \times 10^{-3} \mathrm{~mol} \mathrm{~L}^{-1}$. ISE was used for $\mathrm{Cu}$ titration, while $\mathrm{HADE}$ (hanging amalgam drop electrode) was used for $\mathrm{Pb}, \mathrm{Cd}$ and $\mathrm{Zn}$.

sociated sites at $\mathrm{pH}$ 6.0. On the other hand, admitting the stoichiometry and pKa values for the ionizable sites determined in ionic medium of $0.02 \mathrm{~mol} \mathrm{~L}^{-1} \mathrm{NaNO}_{3}$, and humic acid concentration of $30 \mathrm{mg} \mathrm{L}^{-1}$, the presence of $2,150 \mu \mathrm{mol} \mathrm{g}{ }^{-1}$ of free carboxylate sites would be expected at $\mathrm{pH}$ 6.0. In this case, in addition to the binding involving two carboxylate sites, one can also consider the participation of oxygen donor atoms of carbonyl and alcoholic structures, as well as nitrogen containing groups. At pH 6.0 the most part of phenolic and aminic groups are undissociated so that the participation of these groups in the chelation might lead to liberation of protons in solution. This process was evidenced by the fact that, during the humic acid titrations, a larger amount of the 2 mmol L ${ }^{-1} \mathrm{NaOH}$ was necessary to keep the $\mathrm{pH}$ at $6.00 \pm 0.05$ in comparison to the blank titrations. The additional amount of $\mathrm{OH}^{-}$is equal to the amount of $\mathrm{H}^{+}$liberated from undissociated binding sites during the titra- tion. The total amount of protons liberated per gram of humic acid is shown in Table 3. It is interesting to notice, however, that the amount of protons liberated is very small in comparison to the total complexing capacity of all four metals studied, suggesting that the chelate formation has a major contribution of dissociated carboxylate sites as well as carbonyl and alcoholic oxygen atoms, or nitrogen atoms.

Lead is also complexed in two different kinds of binding sites, but unlike observed for copper, the log K for both classes differ by only 0.6 units. The class 1 plays the major role in lead complexation, corresponding to $75 \%$ of the total complexing capacity. The total $\mathrm{C}_{\mathrm{c}}$ of $2,400 \mu \mathrm{mol} \mathrm{g}-1 \mathrm{of}^{2+}$ corresponds to $85 \%$ of free dissociated groups at $\mathrm{pH} 6.0$, determined in ionic medium of $0.1 \mathrm{~mol} \mathrm{~L}^{-1} \mathrm{NaCl}$. If one considers the results of $\mathrm{pKa}$ and stoichiometry for ionizable sites determined in 0.02 mol L-1 $\mathrm{NaNO}_{3}$ and $30 \mathrm{mg} \mathrm{L}^{-1}$ humic acid, the total of carboxylic sites would be $2,500 \mu \mathrm{mol} \mathrm{g}-1$, or $2,150 \mu \mathrm{mol} \mathrm{g} \mathrm{g}^{-1}$ of 
Table 4. Metal content ${ }^{\mathrm{a}}$ extractable from the sediment and humic acid by the $\mathrm{HNO}_{3} / \mathrm{H}_{2} \mathrm{O}_{2}$ treatment.

\begin{tabular}{|c|c|c|c|c|c|c|}
\hline \multirow[t]{2}{*}{ sample } & \multicolumn{6}{|c|}{ Metal concentration $\left(\mu \mathrm{mol} \mathrm{g}^{-1}\right)$} \\
\hline & $\mathrm{Al}$ & $\mathrm{Fe}$ & $\mathrm{Mn}$ & $\mathrm{Cu}$ & $\mathrm{Zn}$ & $\mathrm{C}(\%)$ \\
\hline sediment & $240 \pm 24$ & $91.2 \pm 0.1$ & $6.22 \pm 0.07$ & $0.77 \pm 0.03$ & $0.47 \pm 0.01$ & $0.50 \pm 0.03$ \\
\hline Humic Acid & 16.0 & 27.0 & $\mathrm{ND}^{\mathrm{b}}$ & 2.49 & 0.50 & 54.1 \\
\hline
\end{tabular}

${ }^{a}$ Results correspond to an average of three experiments; ${ }^{b} \mathrm{ND}=$ not detected.

free carboxylate groups at $\mathrm{pH}$ 6.0. This suggests that formation of bidentade chelates of $\mathrm{Pb}^{2+}$ with the humic acid necessarily would involve oxygen electron-donor atoms of carbonyl and alcoholic structures, as well as with nitrogen containing moieties. As observed for copper, the proton liberation from undissociated groups at $\mathrm{pH} 6.0$ occurs, but corresponds only to a small fraction of the total complexing capacity.

The results for cadmium and zinc were similar, evidencing the formation of weak complexes, as well as low complexing capacity in comparison to those observed for copper and lead. The stability of the complexes as a function of the metal cation may be ordered as $\mathrm{Cu}>\mathrm{Pb}>\mathrm{Cd} \cong$ $\mathrm{Zn}$. These results are in agreement with Slavek et $\mathrm{al}^{2}$, who performed selective extraction of metal cations adsorbed on humic acids with concentrated salt solutions and complexants, verifying that copper was retained in greater extension than lead. Salt solutions extracted only $50 \%$ of copper and lead, while complexants (EDTA, DTPA) extracted more than $90 \%$ of the retained metals. Cadmium and zinc were only weakly bounded, and about $80 \%$ of these metals were extracted with concentrated salt solutions. The order of retention observed for Slavek et $\mathrm{al}^{2}$ was $\mathrm{Cu}>\mathrm{Pb}>\mathrm{Cd}>\mathrm{Zn}$.

\section{Metal content in the humic acid and sediment}

Table 4 shows the metal content that was extracted from the crude sediment by the $\mathrm{HNO}_{3} / \mathrm{H}_{2} \mathrm{O}_{2}$ treatment ${ }^{19}$, as well as the metal content retained in the humic acid through the isolation and purification steps. Lead and cadmium were not detected in these experiments, while copper and zinc were determined in the sediment and in the humic acid. Retention of copper was larger than zinc, in agreement with the stability constants determined by the complexometric titrations. The retention of these metals by the humic fraction of Barra Bonita sediment denotes their strong association with some sites of the natural organic matter. The presence of $\mathrm{Cu}$ and $\mathrm{Zn}$ in the purified humic acid fraction may be explained by their role as micronutrient for plankton and other living organisms, that are precursors of humic substances ${ }^{1}$. The low content of organic carbon $(0.5 \%)$ in the sediment samples of Barra Bonita may be explained by the results of granulometric analysis, which revealed that a fraction of only $24 \%$ is $<63 \mu \mathrm{m}$ (the fraction that is supposed to concentrate the organic matter is the $<20 \mu \mathrm{m}^{27}$ ). If one takes in account only the $<63 \mu \mathrm{m}$ fraction, the organic carbon content is about $12 \%$.

Aluminium and iron are among the major components of the sediments and were determined in significant concentration in the humic acid, suggesting the formation of strong interactions of these metals with natural organic matter. Iron and aluminium may play an important role in the formation of tertiary structure of humic substances.

\section{Conclusions}

The I. H. S. S. extraction procedure was suitable to isolate the humic substance from a sediment rich in clays and sand, providing a material with low ash content. Composition and elemental ratio of the humic acid was very similar to other sedimentary humic acids isolated from very different sampling sites. The content of carboxylic and phenolic sites, that compose the most important binding sites, were also within the range of values reported in the literature for sedimentary humic acids. The stability of the complexes with the four studied metal cations followed the order: $\mathrm{Cu}>\mathrm{Pb}>\mathrm{Cd} \sim \mathrm{Zn}$. The complexing capacity order was: $\mathrm{Pb}>\mathrm{Cu}>\mathrm{Cd} \sim \mathrm{Zn}$.

\section{Acknowledgments}

Authors are grateful to FAPESP and CNPq for financial support and fellowships.

\section{References}

1. Sigg, L. In Buffle, J., de Vitre, R. R. (Eds), Chemical and Biological Regulations of Aquatic Systems, Lewis Publishers, Boca Raton, FL, United States, 1994, pp. 175-195.

2. Slavek, J.; Wold, J.; Pickering W. F. Talanta 1982, 29, 743.

3. Buffle, J. Complexation Reactions in Aquatic Systems: An Analytical Approach, Ellis Horwood Series in Analytical Chemistry, Chichester, 1988.

4. Gulmini, M.; Zelano, V.; Daniele, P. G.; Prenesti, E.; Ostacoli, G. Anal. Chim. Acta 1996, 329, 33. 
5. Gulmini, M.; Zelano, V.; Daniele, P. G.; Prenesti, E.; Ostacoli, G. Anal. Chim. Acta 1998, 358, 195.

6. Stevenson, F.J. Humus Chemistry. Genesis, Composition, Reactions, Wiley Interscience, 2nd Edition, New York, Chichester Brisbane, 1994.

7. Belzile, N.; Joly, H. A.; Li H. Can. J. Chem. 1997, 75, 14.

8. Bernhard, J. P.; Buffle, J.; Parthasarthy, N. Anal.Chim. Acta 1987, 200, 191.

9. Abate, G.; Masini, J. C. Quim. Nova 1999, 22, 661.

10. Wershaw, R. L.; Pinckney, D. J.; Llaguno E. C.; Vicente-Beckett V. Anal. Chim. Acta 1990, 232, 31.

11. Qiang, T.; Xiao-quan, S.; Zhe-ming, N. Fresenius $J$. Anal. Chem. 1993, 347, 330.

12. Mori, S.; Hiraide, M.; Mizuike, A. Anal. Chim. Acta 1987, 193, 231.

13. Kim, J. I.; Buckau, G.; Li, G. H.; Duscher, H.; Psarros N. Fresenius J. Anal. Chem. 1990, 338, 245.

14. Klavins, M.; Apsite, E. Environment International 1997, 23, 783.

15. Pehrson, L.; Ingman, F.; Johansson, A. Talanta 1976, 23, 769.

16. Masini, J. C.; Abate, G.; Lima, E. C.; Hahn, L. C.; Nakamura, M. S.; Lichtig, J.; Nagatomy, H. R. Anal.
Chim. Acta 1998, 364, 223.

17. Aleixo, L. M.; Godinho, O. E. S.; Costa, W. F. Anal. Chim. Acta 1992, 257, 35.

18. Masini, J. C. Anal. Chim. Acta 1993, 283, 803.

19. Thompson, M.; Wood, S. J. In Cantle, J.E. (Ed). Atomic Absorption Spectrometry, 5, 1982, pp. 261284.

20. Ishiwatari, R. In Aiken G. R. (Ed). Humic Substances in Soil, Sediment and Water, John Wiley, New York, 1985, pp. 147-180.

21. Meyer, P. E.; Ishiwatari, R. Org. Geochem. 1993, $20,867$.

22. Perminova, I. V.; Frimmel, F. H.; Kovalevskii, D. V.; Abbt-Braun, G.; Kudryavtsev, A. V.; Hesse, S. Water Res. 1998, 32, 872.

23. Leenheer, J. A.; Wershaw, R. L.; Reddy, M. M. Environ. Sci. Technol. 1995, 29, 399.

24. Leenheer, J. A.; Wershaw, R. L.; Reddy, M. M. Environ. Sci. Technol. 1995, 29, 393.

25. Falzoni, A.; Seeber, R.; Tonelli, D.; Ciavatta, C.; Gessa, C.; Montecchio, M. Analusis 1998, 26, 214.

26. Scatchard, G. Ann. N. Y. Acad. Sci. 1949, 51, 660.

27. Ackerman, F.; Bergman, H.; Schlelechert, U. Environ. Technol. Lett. 1983, 4, 317.

Received: April 18, 2000

Published on the web: October 25, 2000

FAPESP helped in meeting the publication costs of this article. 